\title{
Standardization, Formulation and Evaluation of Food Products Developed from Gluten Free Flour Mix
}

\author{
Latika Yadav $^{1 *}$ and Anchal Yadav ${ }^{2}$ \\ ${ }^{1}$ Department of Food and Nutrition, Faculty of Home Science, \\ Bindheswari P.G. College, Akbarpur, U.P., India \\ ${ }^{2}$ Department of Food and Nutrition, Faculty of Home Science, \\ Bindheswari P.G. College, Akbarpur, U.P., India
}

*Corresponding author

\section{A B S T R A C T}

\begin{tabular}{|l|}
\hline Key w or d s \\
Gluten free \\
flour mix, \\
Standardization, \\
Formulation, \\
Sensory \\
\hline Article Info \\
\hline $\begin{array}{l}\text { Accepted: } \\
\text { 11 June 2020 } \\
\text { Available Online: } \\
\text { 10 July } 2020\end{array}$ \\
\hline \hline
\end{tabular}

\section{Introduction}

Celiac disease is a genetically determined chronic inflammatory intestinal disease induced by gluten in wheat, barley, rye etc. Celiac disease affects approximately $1 \%$ of people in the world and strict gluten free diet (Prakiti et al., 2016). Patients shows nutritional deficiencies could, either temporally or during a longer period, require supplementation of their diets with vitamins, minerals and proteins to correct deficiencies and store nutrients reserves; recent studies, however have not considered specifically the efficacy of extra intake of nutrients in the celiac disease treatments (Raymond et al., 2006).There is no specific definition for health foods but generally used for all the foods that provide health benefit beyond nutrition. Health foods is thus, used as an umbrella term encompassing functional foods, nutraceutical, designer foods, along with all natural foods, whole foods and sometimes even dietary supplements (Vaughan and Judd, 2003). 
Cereals and millets have been an essential part of the human diet since the beginning of agriculture. Cereals and millets used for human consumption belong to the grass family and are seed of matured plants, in which nature has stores the elements for the germination and growth of the germ such as starch, fat, protein, organic minerals salts and vitamins (Manavi and Mamta, 2015).

Buckwheat flour was a better source of macro and microelements compared to maize gluten free flour (Zuzana et al., 2016). Although oats are included in the list of gluten free ingredient specified in European regulations, their safety when consumed by celiac patients remains debatable. Some studies claim that pure oats safe for most celiac people, and contamination with other cereal sources is the main problem facing people with disease (Isabel et al., 2015). Protein contents in buckwheat flour have been reported to range from 8.5 to $18.9 \%$ depending on the variety (Krkoskova and Mrazova, 2005). Ragi is minor millet consumed by the economically weaker section of the population of especially by South India rural folk. It is hardy crop that provide high quality nutrition at a low price. Ragi is also known as Madua or finger millet or nachni grows well without irrigation pesticides or fertilizer. It is underutilized grain which is inexpensive, easy to cook and rich in vitamin and minerals (Manavi and Mamta, 2015). Amaranth grains are rich in lysine and tryptophan. Grain amaranth has several attractive features like gluten free ingredient, high quality protein and the presence of abundant quantities of fibre and minerals such as calcium and iron (Ballabio et al., 2011).

Fava bean also referred to as broad bean and field bean is an early legume crop. The nutritional importance of fava beans is prominent approximately $250 \mathrm{gm}$ protein $/ \mathrm{kg}$ seed. The amount of energy in fava beans 320 $\mathrm{kcal} / 100 \mathrm{gm}$ on dry matter. Millets and legumes, which have a high nutritional value, were applied in the production of enriched gluten free food products. Diet based on gluten free products is often characterized by low contents of some nutritional components, as well as non- nutritional but physiologically important components like dietary fibre. This is the reason; efforts are made to standardize, formulate and evaluate gluten-free flour mix products especially rich in protein, fiber, macro, and microelements, and their organoleptic evaluation.

\section{Materials and Methods}

The methodological details of experiment conducted during the course of investigation have been portrayed under the following sub headings:

\section{Standardization of gluten free flour mix recipes}

Raw materials namely ragi, amaranth, fava bean and buckwheat and other ingredients were procured in bulk from Sahazadpur, Akbarpur market of Ambedkar Nagar District, Uttar Pradesh, India. In the present study recipes were standardized and developed by the use of Gluten Free Flour Mix. Gluten free flour mix was formulated by conducting 6 treatments using millets and legume viz. Ragi, Amaranth, Buckwheat and Fava bean. The ratio of Gluten free flour mix $25 \mathrm{~g}$ of ragi, $25 \mathrm{~g}$ of amaranth, $25 \mathrm{~g}$ of fava bean flour and $25 \mathrm{~g}$ of buckwheat flour was found to be the best acceptable formulation. The acceptable combination of GFFM was used in the preparation of various food products. Gluten Free Flour Mix recipes and control recipes prepared by different cooking methods viz. deep frying and baking. Recipes were standardized to achieve the desirable color, flavor, texture, taste, appearance and overall acceptability. 


\section{Poori}

Gluten Free Flour Mix (100gm), ajwain seeds (2gm), salt (according to taste) were mixed properly. Knead soft dough with the help of water as required. It should be softer than chapatti dough. Make small balls of dough and rolled into small sized chappati with rolling pin. Heat the oil in a frying fan then deep fried till puff and golden brown in colour from both sides.

\section{Litti}

Knead soft dough of gluten free flour mix $(100 \mathrm{gm})$ and salt (according to taste) with the help of water as required. It should be softer than chapatti dough. For stuffing in roasted gram flour(100gm) add slightly crushed cumin, fennel, ajwain, nigella seeds, red chilli powder, dry mango powder, crushed garlic, chopped green chillies, ginger and onion into it. Also add chopped coriander leaves, salt, lemon juice, mustard oil and mango pickle in the mixture. The sattu stuffing mixture should not be too dry or too wet. Now make medium sized balls from the dough, roll each dough ball to a circle of about 5-6 inches. Place 2 tbsp of the stuffing in the centre, fold the edges, press the joined part and lightly roll the stuffed dough balls in your palms, so as to get a round shape. Deep fry the litti into hot oil on slow flame.

\section{Cake}

Preheat oven at $180^{\circ} \mathrm{C}$ for 10 minutes. Gluten free flour mix (100gm), baking soda (1.5gm), baking powder $(1.5 \mathrm{gm})$ and chocolate powder $(20 \mathrm{gm})$ were sieved together and mix properly. The butter $(50 \mathrm{gm})$ and sugar $(50 \mathrm{gm})$ was creamed together in a large bowl and creamed well until fluffy. Then add dry ingredients and blend properly. Finally the carbonated beverages and vanilla essence (20 drops) were added to the mixture and blended for 2 minutes to improve the quality of batter and final product. The batter was filled into the dusted cake moulds and baked at $180^{\circ} \mathrm{C}$ for 35-40 minutes.

\section{Mathri}

Gluten free flour mix (100gm), ajwain seeds (2gm), salt (according to taste) and refined oil $(10 \mathrm{ml})$ were mixed properly. Knead hard dough with the help of warm water as required. It should be tighter than chapatti dough. Divide the dough into half, dust with flour and roll slightly thick as of poori and use a cookie cutter/glass to cut small round mathri. Prick the mathri with a fork to prevent from puffing up. Fry the mathri in medium hot oil on low flame till the mathri floats and golden brown in colour.

\section{Handmade Sewai/ Jawe}

Knead soft dough of gluten free flour mix $(100 \mathrm{gm})$ with the help of water as required. It should be softer than chapatti dough. Take small-small amount from dough and extrude sewai with hand and sun dried for 2 days.

\section{Sensory Evaluation}

The prepared gluten free flour mix recipes were organoleptically evaluated by semitrained ten panels of judges. For the selection of panel members threshold test is used. The gluten free flour mix was evaluated for various sensory quality characteristics such as color, flavor, taste, texture, appearance, and overall acceptability.

Evaluation of the product was done on the basis of 9 point hedonic scale. The test sample was given in triplicates with control. Control sample was prepared from the usual recipes. All samples were coded to avoid any type of biasness. 


\section{Statistical analysis}

Statistically, all the collected data on organoleptic evaluation were analyzed. Data were presented as mean \pm S.D. Analysis of Variance (ANOVA) was used to assess the sensory characteristics of gluten free flour mix recipes.The data obtained (in triplicate) were evaluated statistically with OPSTAT package program (OPSTAT software for Windows).

\section{Results and Discussion}

The present study was based on the standardization, formulation and evaluation of gluten free flour mix recipes viz. Poori, Litti, Cake, Mathri and Sewai. The developed products were tested for their sensory evaluation for the most acceptable level from the control recipes and the prepared samples were also analyzed for their nutrient content. All the products were prepared by using wheat flour for control samples and for the test samples the standard recipes were totally replaced by gluten free flour mix ( amaranth, ragi, buckwheat and fava bean flour) to obtained sensory acceptable by the panel of judges .

The mean sensory scores of Poori have been presented in Table 1. It is clearly visible from the data that gluten free flour mix poori sensory score was found to be ranked as the highest in all sensory parameters viz., $8.55 \pm 0.13$ for color, $8.62 \pm 0.14$ for flavor, $8.57 \pm 0.12$ for texture, $8.67 \pm 0.20$ appearance, $8.65 \pm 0.13$ for taste and $8.47 \pm 0.06$ for overall acceptability as the control. The acceptability scores of control and test poori ranged between $8.40 \pm 0.14$ to $8.62 \pm 0.118 .47 \pm 0.06$ to $8.67 \pm 0.20$ indicating that the test poori and control both fell under the category of "Liked very much. Similarly, Bhathaland kaur (2018) prepared a paratha from gluten free quinoa flour and found that the test sample were highly acceptable as compared to control sample and the overall acceptability score was 8.04. Table 2 showed the mean acceptability scores of wheat flour Litti (control) and gluten free flour mixLitti (test sample) .Testlitti obtained higher score viz., $8.42 \pm 0.14$ for color, $8.52 \pm 0.18$ for flavor, $8.45 \pm 0.26$ for texture, $8.75 \pm 0.09$ for appearance, $8.55 \pm 0.15$ for taste and $8.46 \pm 0.10$ for overall acceptability whereas control litti scores viz., $8.30 \pm 0.09$ for color, $8.22 \pm 0.18$ for flavor, $8.32 \pm 0.15$ for texture, $8.60 \pm 0.17$ for appearance, $8.45 \pm 0.06$ for taste and $8.35 \pm 0.10$ for overall acceptability. Statistically significant difference was found between control and test samples.

Result presented in table 3 depicted that gluten free flour mix cake was more appreciated as compared to the wheat flour cake (control). On an overall acceptability basis test cake $8.54 \pm 0.03$ scored was higher as compared to control cake $8.44 \pm 0.13$ was "Liked very much" by the panel members with regards to all sensory attributes. Gluten free flour mix cake obtained higher score viz., $8.67 \pm 0.09$ for color, $8.65 \pm 0.06$ for flavor, $8.60 \pm 0.14$ for texture, $8.70 \pm 0.10$ for appearance and $8.52 \pm 0.48$ for taste whereas control cake scores viz., $8.45 \pm 0.14$ for color, $8.50 \pm 0.21$ for flavor, $8.42 \pm 0.08$ for texture, $8.52 \pm 0.14$ for appearance, $8.50 \pm 0.12$ for taste and $8.44 \pm 0.13$ for overall acceptability. Thirukkumar et al., (2017) prepared gluten free cake mix by using dehulled chickpea flour, barnayard millet flour and corn flour and found that the cakes containing highest levels of pulse flour and barnyard millet flour levels were rated high due to their overall acceptability by sensory evaluation.

It is clearly visible from the data in the Table 4 that gluten free flour mixmathri sensory score was found to be ranked as the highest in all sensory parameters viz., $8.60 \pm 0.09$ for color, $8.52 \pm 0.06$ for flavor, $8.60 \pm 0.04$ for 
texture, $8.67 \pm 0.19$ appearance, $8.65 \pm 0.10$ for taste and $8.52 \pm 0.09$ for overall acceptability than the wheat flour mathri. The acceptability scores of control and test mathri ranged between $8.52 \pm 0.06$ to $8.67 \pm 0.19$ and 8.33 \pm 0.10 to $8.60 \pm 0.10$ indicating that testmathri and control both fell under the category of "Liked very much" on nine point hedonic scale. Statistically significant difference was reported between control and test samples. Similarly, Bhathal and Kaur (2018) prepared a mathri from gluten free quinoa flour and found that the test sample were highly acceptable as compared to control sample and the overall acceptability score was 7.02.

Table.1 Mean acceptability scores of Poori

\begin{tabular}{|c|c|c|}
\hline Sensory Parameters & $\begin{array}{c}\text { Poori prepared from } \\
\text { wheat flour }\end{array}$ & $\begin{array}{c}\text { Poori prepared from } \\
\text { Gluten free flour mix }\end{array}$ \\
\hline Color & $8.45 \pm 0.10$ & $8.55 \pm 0.13$ \\
\hline Flavor & $8.40 \pm 0.14$ & $8.62 \pm 0.14$ \\
\hline Texture & $8.50 \pm 0.09$ & $8.57 \pm 0.12$ \\
\hline Appearance & $8.62 \pm 0.11$ & $8.67 \pm 0.20$ \\
\hline Taste & $8.45 \pm 0.06$ & $8.65 \pm 0.13$ \\
\hline Overall acceptability & $8.45 \pm 0.11$ & $8.47 \pm 0.06$ \\
\hline
\end{tabular}

Table.2 Mean acceptability scores of Litti

\begin{tabular}{|c|c|c|}
\hline Sensory Parameters & $\begin{array}{c}\text { Litti prepared from } \\
\text { wheat flour }\end{array}$ & $\begin{array}{c}\text { Litti prepared from } \\
\text { Gluten free flour mix }\end{array}$ \\
\hline Color & $8.30 \pm 0.09$ & $8.42 \pm 0.14$ \\
\hline Flavor & $8.22 \pm 0.18$ & $8.52 \pm 0.18$ \\
\hline Texture & $8.32 \pm 0.15$ & $8.45 \pm 0.26$ \\
\hline Appearance & $8.60 \pm 0.17$ & $8.75 \pm 0.09$ \\
\hline Taste & $8.45 \pm 0.06$ & $8.55 \pm 0.15$ \\
\hline Overall acceptability & $8.35 \pm 0.10$ & $8.46 \pm 0.10$ \\
\hline
\end{tabular}

Table.3 Mean acceptability scores of Cake

\begin{tabular}{|c|c|c|}
\hline Sensory Parameters & $\begin{array}{c}\text { Cake prepared from } \\
\text { wheat flour }\end{array}$ & $\begin{array}{c}\text { Cake prepared from } \\
\text { Gluten free flour mix }\end{array}$ \\
\hline Color & $8.45 \pm 0.14$ & $8.67 \pm 0.09$ \\
\hline Flavor & $8.50 \pm 0.21$ & $8.65 \pm 0.06$ \\
\hline Texture & $8.42 \pm 0.08$ & $8.60 \pm 0.14$ \\
\hline Appearance & $8.52 \pm 0.14$ & $8.70 \pm 0.10$ \\
\hline Taste & $8.50 \pm 0.12$ & $8.52 \pm 0.48$ \\
\hline Overall acceptability & $8.44 \pm 0.13$ & $8.54 \pm 0.03$ \\
\hline
\end{tabular}


Table.4 Mean acceptability scores of Mathri

\begin{tabular}{|c|c|c|}
\hline Sensory Parameters & $\begin{array}{c}\text { Mathriprepared } \\
\text { from wheat flour }\end{array}$ & $\begin{array}{c}\text { Mathriprepared from } \\
\text { Gluten free flour mix }\end{array}$ \\
\hline Color & $8.40 \pm 0.20$ & $8.60 \pm 0.09$ \\
\hline Flavor & $8.37 \pm 0.13$ & $8.52 \pm 0.06$ \\
\hline Texture & $8.35 \pm 0.10$ & $8.60 \pm 0.04$ \\
\hline Appearance & $8.60 \pm 0.10$ & $8.67 \pm 0.19$ \\
\hline Taste & $8.40 \pm 0.12$ & $8.65 \pm 0.10$ \\
\hline Overall acceptability & $8.33 \pm 0.10$ & $8.52 \pm 0.09$ \\
\hline
\end{tabular}

Table.5 Mean acceptability scores of handmade Sewai

\begin{tabular}{|c|c|c|}
\hline Sensory Parameters & $\begin{array}{c}\text { Handmade sewai prepared } \\
\text { from wheat flour }\end{array}$ & $\begin{array}{c}\text { Handmade sewai prepared } \\
\text { from Gluten free flour mix }\end{array}$ \\
\hline Color & $8.50 \pm 0.17$ & $8.65 \pm 0.06$ \\
\hline Flavor & $8.32 \pm 0.11$ & $8.60 \pm 0.12$ \\
\hline Texture & $8.07 \pm 0.18$ & $8.40 \pm 0.10$ \\
\hline Appearance & $8.12 \pm 0.19$ & $8.25 \pm 0.13$ \\
\hline Taste & $8.47 \pm 0.18$ & $8.67 \pm 0.04$ \\
\hline Overall acceptability & $8.15 \pm 0.01$ & $8.32 \pm 0.09$ \\
\hline
\end{tabular}

Table.6 Nutrient content of standardized products prepared from wheat flour and gluten free flour mix

\begin{tabular}{|c|c|c|c|c|c|c|c|c|}
\hline \multicolumn{2}{|c|}{$\begin{array}{c}\text { Developed } \\
\text { Products }\end{array}$} & $\begin{array}{l}\text { Protein } \\
\text { (g) }\end{array}$ & $\begin{array}{l}\text { Fat } \\
\text { (g) }\end{array}$ & $\begin{array}{c}\text { Fibre } \\
\text { (g) }\end{array}$ & $\begin{array}{c}\text { Carbohydrate } \\
\text { (g) }\end{array}$ & $\begin{array}{l}\text { Energy } \\
\text { (kcal) }\end{array}$ & $\begin{array}{c}\text { Calcium } \\
\text { (mg) }\end{array}$ & $\begin{array}{l}\text { Iron } \\
(\mathbf{m g})\end{array}$ \\
\hline \multirow[t]{2}{*}{ Poori } & Control & 10.57 & 16.53 & 11.36 & 64.17 & 1475 & 30.94 & 4.10 \\
\hline & GFFM & 12.97 & 17.75 & 12.29 & 59.27 & 1219 & 171.05 & 8.59 \\
\hline \multirow[t]{2}{*}{ Litti } & Control & 18.07 & 18.57 & 21.44 & 79.99 & 1955 & 90.94 & 6.82 \\
\hline & GFFM & 20.47 & 19.79 & 22.37 & 75.09 & 1699 & 231.05 & 11.31 \\
\hline \multirow[t]{2}{*}{ Cake } & Control & 11.28 & 41.34 & 2.76 & 116.7 & 2576 & 73.9 & 4.08 \\
\hline & GFFM & 13.09 & 43.33 & 12.29 & 101.7 & 2191 & 260.85 & 10.94 \\
\hline \multirow[t]{2}{*}{ Mathri } & Control & 10.36 & 15.76 & 2.76 & 74.27 & 1607 & 7.49 & 0.65 \\
\hline & GFFM & 12.97 & 17.75 & 12.29 & 59.27 & 1219 & 171.05 & 8.59 \\
\hline \multirow[t]{2}{*}{ Sewai } & Control & 10.57 & 1.53 & 11.36 & 64.17 & 1340 & 30.94 & 4.10 \\
\hline & GFFM & 12.97 & 2.75 & 12.29 & 59.27 & 1084 & 171.05 & 8.59 \\
\hline
\end{tabular}

Values are expressed from $100 \mathrm{gm}$ of edible portion

It is evident from the result in Table 5 that gluten free flour mixsewai was more appreciated as compared to the control. On an overall acceptability basis, testsewai 8.32 \pm 0.09 scored was higher as compared to control $8.15 \pm 0.01$. Gluten free flour mix 
sewai was "Liked very much" by the panel members with regards to all sensory attributes. GFFM sewai obtained higher scores viz., $8.65 \pm 0.06$ for color, $8.60 \pm 0.12$ for flavor, $8.40 \pm 0.10$ for texture, $8.25 \pm 0.13$ for appearance, $8.67 \pm 0.04$ for taste and 8.32 \pm 0.09 for overall acceptability. Silvana et al., (2014) conducted a study on making gluten free noodles for celiac people and the evaluation of sensorial characteristics. They reported that the test gluten free noodles were highly acceptable on their sensory scores as compared to control noodle samples.

Nutritional composition of developed food products viz. poori, litti, cake, mathri and handmade sewai presented in Table 6. Total ten recipes were developed five of control and five of gluten free flour mix. On the nutritional basis result revealed that the gluten free flour mix products were rich in protein, fat, fibre, calcium and iron except carbohydrate and energy as compared to control. Gluten free flour mix litti scored higher in protein $20.47 \mathrm{~g}$, fibre $22.37 \mathrm{~g}$ and iron $11.31 \mathrm{mg}$ as compared to all developed food products and control litti, whereas test cake scored high in calcium $260.85 \mathrm{mg}$ followed by testlitti $231.05 \mathrm{mg}$ as compared to all developed food products. It was clearly depicted that the gluten free flour mix food products were rich in nutrient content and the score ranged between for Protein 12.97 to $20.47 \mathrm{~g}$, Fat 2.75 to $43.33 \mathrm{~g}$, Fibre 12.29 to $22.37 \mathrm{~g}$, carbohydrate 59.27 to $101.7 \mathrm{~g}$, Energy 1084 to $1291 \mathrm{kcal}$, Calcium 171.05 to 260.85 $\mathrm{mg}$ and Iron 8.59 to $11.31 \mathrm{mg}$. Bhathan and Kaur (2018) prepared a gluten free products from quinoa flour i.e.ladoo, chapatti, parantha, mathri, cookies and pop-ups. Nutritional analysis revealed that test samples prepared from quinoa flour have higher crude protein ranging from 11.02 to 15.00 percent, crude fat 4.09 to 59.14 percent, total ash 1.75 to 4.19 percent and crude fibre 0.27 to 3.24 percent as compared to controls. Gluten free quinoa flour products were found to be highly acceptable and nutritionally better as compared to the control samples. Thirukkumar et al., (2017) developed gluten free cake mix using dehulled chickpea flour (50 to $80 \mathrm{~g} / 100 \mathrm{~g}$ ), barnyard millet flour (0 to $30 \mathrm{~g} / 100 \mathrm{~g}$ ) and corn flour (20 to $30 \mathrm{~g} / 100 \mathrm{~g}$ ). The results showed that the protein and fiber content varied from 14.79 - 23.87 and 3.94 $5.8 \mathrm{~g}$ per $100 \mathrm{~g}$ of gluten free cake respectively, depending on the experimental condition. The optimum flour combination for development of gluten free cake mix was $64.85 \mathrm{~g}$ of chickpea flour, $30 \mathrm{~g}$ of barnyard millet flour and $5.15 \mathrm{~g}$ of corn flour.

Research studies revealed that the products made from gluten free flour mix were found to be highly acceptable and obtained higher scores as compared to control. Thus on the basis of sensory scores it can be concluded that gluten free flour mix can be effectively used in developing nutrient rich food products for people suffering from gluten intolerance and low income groups.

\section{References}

Ballabio, C., Uberti, F., Di. Lorenzo, C., Brandolini, A., Penas, E., and Restani P. 2011. Biochemical and immunochemical characterization of different varities of amaranth (Amaranthus L. ssp) as a safe ingredient for gluten free products. Journal of Agricultural and Food Chemistry, 59: 12969-12974.

Bhathal, S.K. and Kaur, N., Nutritional Analysis of Gluten Free Products from Quinoa (Chenopodium quinoa) Flour, Int. J. Pure App. Biosci. 6(2): 826-836 (2018).

ManviRastogi and Mamta Joshi. 2015. Effect of Ragi (Eleusiane coracana) for the development of value added products and their nutritional implications. 
Associative Journal of Health Sciences, 10: 1-5.

Isabel Comino, Maria de. Louders Moreno, Carolina Sousa. 2015. Role of oats in celiac disease. World Journal of Gastroenterology, 21: 11825-11831.

Krkoskova B and Mrazova Z. 2005.

Prophylactic components of Buckwheat.

Food Research International, 38: 561568.

Prakriti Jnawali, Vikas Kumar, Beenu Tanwar. 2016. Celiac Disease: Overview and consideration for development of gluten- free foods. Food Science and Human Wellness.5:169176.

Raymond. N., Hcap, J., Casc, S. 2006. The Gluten free diet: An update for Health Professional. Practice

Gastroenterology, 30:67-92.

Silvana Beatriz Sabbatini, Hugo Diego Sanchez, Maria Adela de la Torre, Carlos Alberto Osella. Design of a
Premix for Making Gluten Free Noodles. International Journal of Nutrition and Food Sciences. Vol. 3, No. 5, 2014, pp. 488-492.

Thirukkumar Subramani, Hemalatha Ganapathy and Senthamaraiselvi Lakshmanan. 2017. Standardization of Gluten Free Chickpea Flour Based Cake Mix by Using Response Surface Methodology. Int.J.Curr.Microbiol. App.Sci. 6(8): 963-974.

Vaughan, P.A. Judd.2003. Health Foods- A comprehensive Guide to Natural Remidies. Oxford University Press New York.

ZuzanaCiesarova, Eva Basil, Kristina Kukurova, Lucie Markova, Henryk Zielinski and Malgorzata Wronkowska. 2016. Gluten-free muffins based on fermented and unfermented buckwheat flour- content of selected elements. Journal of Food and Nutrition Research. 55: 108-113.

\section{How to cite this article:}

Latika Yadav and Anchal Yadav. 2020. Standardization, Formulation and Evaluation of Food Products Developed from Gluten Free Flour Mix. Int.J.Curr.Microbiol.App.Sci. 9(07): 10371044. doi: https://doi.org/10.20546/ijcmas.2020.907.121 